Piotr Prósinowski, Piotr Krzywdziński

Uniwersytet Gdański

\title{
Gry wideo a postawa twórcza: potencjał i narracja zagrożeń
}

\section{Wstęp}

Gry wideo w opinii społecznej wydają się być nacechowane specyficzną ambiwalencją. Z jednej strony z wolna zyskują akceptację, stają się stałym elementem głównego nurtu współczesnej kultury. Z drugiej wciąż wiąże się nimi wiele negatywnych stereotypów. Od lat bywają łączone z uzależnieniami, promowaniem agresji i okrucieństwa, oskarżane o „ogłupianie” młodego odbiorcy (Prósinowski 2013). W 2009 roku na portalu Gamezilla.pl pojawiła się krytyka artykułu, którego autor mówi wprost, że gry wideo łączą się z przemocą seksualną i przedstawiają negatywne wzorce ${ }^{1}$.

Media - między innymi prasa, telewizja, portale informacyjne - z mniejszymi lub większymi sukcesami budują wizerunek gier jako „demonicznych zabawek”. Często łączą jednostkowe, oderwane od kontekstu przypadki destrukcyjnych zachowań społecznych z elektroniczną rozrywką, opierając się na bardziej niż wątpliwych logicznie przesłankach. Popularne programy telewizyjne - jak na przykład serial paradokumentalny Szkoła (Głowacki 2014) - jeśli już ukazują gry wideo, to jako uzależniające i budzące agresję. Podobnie ma się kwestia przedstawiania gier w programach talk-show typu Rozmowy w toku (Hofer 2014) ${ }^{2}$ czy serialach jak Ojciec Mateusz (Żmijewski 2014) - w przypadku tego drugiego doszło do tak groteskowego przedstawienia gier oraz osoby gracza, że odcinek serialu doczekał się odpowiedzi w postaci komentarza portali branżowych (Liebert, Łukański, Pitala 2014).

Tego typu produkcje praktycznie nie ukazują potencjału gier, nie mówią o ich związku z kulturą czy poruszanych w nich kwestiach społecznych. Jeśli natomiast gry wideo pojawiają się w popularnych mediach publicznych (spoza obszaru branży gier) w kontekście pozytywnym, ma to zazwyczaj charakter incydentalny. Przedstawiane są w formie ciekawostki, traktowanej zwykle dystansem i w sposób nader powierzchowny.

\footnotetext{
1 Przykładowa wypowiedź analizowana na portalu Gamezilla.pl: „[...] na takie wzorce trafiają choćby w grach komputerowych, których fabuła zasadza się na tym, żeby schwytać dziewczynę i zbiorowo zgwałcić" (Olszewski 2011).

2 Jest to odcinek przykładowy - temat ten poruszano w programie kilkakrotnie.
} 
Informacje nacechowane mocno negatywnie i (często) stronniczo znajdziemy także na quasi-pedagogicznych portalach. Przykładem na to jest artykuł Wptyw gier komputerowych na zdrowie psychiczne i fizyczne dziecka, w którym padają oskarżenia:

Z drugiej strony ta "nowoczesna forma zabawy” często przeraża ogromnym ładunkiem przemocy i wyrafinowanego okrucieństwa, budząc uzasadniony niepokój wychowawców, psychologów i pedagogów co do negatywnego wpływu tych treści na rozwój dziecka. [...] Zaniepokojeni rodzice szukają pomocy u psychologa, ale często dopiero wówczas, gdy dzieci są już silnie uzależnione od grania: gdy mają zaniki mięśni od siedzenia przy komputerze, gdy nie chodzą do szkoły, nie myją się i przez wiele dni nic nie jedzą (Zielińska 2015).

Oczywiście artykuł nie jest poparty żadnymi badaniami, nazwami organizacji i innymi danymi - także o samym autorze nie dowiadujemy się niczego, poza imieniem i nazwiskiem. Czytelnikowi zostaje zaprezentowana niemalże apokaliptyczna wizja dziecka uzależnionego, zagłodzonego, z zanikiem mięśniowym. Winą za to obarcza się gry. Brakuje natomiast refleksji nad stanem, w jakim dotknięta problemem osoba się znalazła - jak wyglądało jej życie psychiczne, relacje z rówieśnikami i rodziną. Nie sposób wręcz uniknąć wrażenia, że symptomy mylone są ze źródłem problemu.

Można więc dojść do wniosku, że medialny wizerunek gier wideo opiera się na budzeniu lęku i niepokoju, tym samym oznaczając gry jako skrajnie niebezpieczne oraz doprowadzające swoich odbiorców do zagłady.

Jednocześnie w obszernej narracji skoncentrowanej na zagrożeniach pomija się aspekty pozytywne. Kontakt z nowymi mediami i technologią informacyjną często stanowi jedno z pierwszych doświadczeń wprowadzających młodego człowieka w uczestnictwo w kulturze. Łatwość dostępu, atrakcyjna forma mogą zachęcać do zapoznania się także z bardziej konwencjonalnymi kanałami transmisji kultury. Przekłada się to również na konwergencję pomiędzy różnymi dziedzinami kultury. Kontakt z medium elektronicznym może na przykład stanowić wstęp do pierwszych doświadczeń czytelniczych (Zając 2013). Nowoczesne urządzenia coraz częściej dysponują przystępnym i prostym w obsłudze interfejsem oprogramowania, który ułatwia dostęp do prezentowanych treści. Dzięki intuicyjnemu charakterowi pozwala przezwyciężyć część ograniczeń wynikających ze sprawności fizycznej bądź bariery wiedzy i umiejętności technicznych (Bougsiaa 2013). Gry wideo - jak wszystkie inne teksty kultury - wprowadzają odbiorcę w świat licznych odniesień do aktualnych problemów życia społecznego, historii, innych form twórczości. Dają możliwość zapośredniczonego obcowania z bardziej tradycyjnymi dziełami poprzez aktywne odnoszenie się do nich. Wszystko to niesie ze sobą znaczny potencjał edukacyjny, szczególnie w zakresie pedagogiki kultury. Stanowią też obszerne pole badań i analiz dla pozostałych nauk społecznych, jak psychologia, socjologia czy nauki polityczne.

Gry są produktami, które mogą wywierać na odbiorcę tak negatywny, jak i pozytywny wpływ. W związku z tym rodzi się pytanie o etyczność mediów względem tworzenia ujednoliconego wizerunku gier wideo - wizerunku demonicznego, 
patogennego, doprowadzającego do wyniszczenia organizmu - pozostawiając w cieniu inne możliwe ich wpływy.

Taki obraz gier jest wzmacniany przez sytuację, w której studia pedagogiczne nie wydają się przybliżać przyszłym nauczycielom, wychowawcom i animatorom życia społecznego problematyki gier wideo oraz ich miejsca we współczesnej kulturze.

Zadaniem tego artykułu nie jest próba usprawiedliwienia wszystkich gier, a ukazanie innego oblicza tej części kultury. Nie zaprzeczamy także istnieniu gier, które mogą wywierać negatywny wpływ na młodszych odbiorców. Naszym celem jest ukazanie symboli, motywów, archetypów wykorzystanych w grach; problemów, wokół których gry budują swoją historię; wyróżnienie pewnych argumentów za głębszą i solidniejszą analizą tego gatunku tekstu kultury - wszystko to poprzez naszkicowanie możliwych dialogicznych sytuacji pomiędzy grami i odbiorcami gier, ich twórczymi przejawami oraz próbami tworzenia ścieżki własnego rozwoju. Ukazanie drugiego oblicza gier wideo jest istotne nie tylko dla pedagogiki, ale także dla samych nauk społecznych, które nie mogą izolować się od tego, co nowe i cyfrowe; od tego, co kształtuje kulturę współczesną oraz napędza znaczące dyskusje społeczne.

\section{Interakcja pomiędzy graczem a grą wideo}

Charakteryzując relacje pomiędzy ludźmi a grami, skupimy się na komputerowych grach fabularnych - zarówno nowszych, jak i starszych dostępnych na rynku. Przyjmujemy, że gry wideo są rodzajem tekstu kultury (Szeja 2004: 8). To znaczy, że stanowią swego rodzaju obraz społecznych przekonań oraz oczekiwań, ponieważ są pisane na postawionych przez autorów i deweloperów fundamentach: poglądach twórców oraz domniemanych pragnieniach graczy. Podczas procesu tworzenia dochodzi do połączenia dwóch elementów. Z jednej strony oczekiwań twórców względem swojej gry. Z drugiej zaś deweloperzy wzbogacają swą idee o elementy, które w ich opinii są pożądane i oczekiwane przez potencjalnych odbiorców. Napięcie między tymi aspektami przybiera różne formy. Mimo wszystko trudno zaprzeczyć, że wraz z rozwojem elektronicznej rozrywki zmianie ulegają również preferencje samych graczy, do których deweloperzy starają się dopasować, by uzyskać lepsze wyniki sprzedaży. Tematyka relacji pomiędzy zamysłami twórców a ich przekonaniami co do oczekiwań graczy jest złożona i mogłaby doczekać się osobnego opracowania. Skupmy się jednak na jednym z aspektów będących jej wynikiem, a mianowicie na typach interakcji ze środowiskiem gry.

Jedną z najbardziej charakterystycznych cech gier fabularnych jest ich immersyjność, czyli zdolność do wywoływania w odbiorcy poczucia zanurzenia w świecie fikcyjnym (Filiciak 2006: 62). Ten jest konstruowany na podstawie zarówno uświadomionych, jak i nieuświadomionych przekonań, oczekiwań i sposobów pojmowania świata przez twórców, a także ich przypuszczeń co do oczekiwań przyszłych odbiorców. Uniwersum gry jest więc strukturalnie spokrewnione z naszą rzeczywistością i jej elementami. Koresponduje z nimi, zachowując pewien zasób 
części wspólnych. Gry dążą chociażby do oddania dynamiki i charakteru procesu podejmowania decyzji na różnym poziomie - czy to doboru przedmiotów dla postaci, czy rozwiązywania dylematów fabularnych (jeden z główny elementów gatunku cRPG). Zygmunt Bauman i Tim May (2004) zauważają, że podejmowanie decyzji i próby rozwiązywania problemów kształtują człowieka i czynią go tym, kim jest. Tak też w grach decyzyjność, związane z nią dylematy i wyzwania często zdają się stanowić o istocie rozgrywki. Gry, działając immersyjnie, rzucają graczy $\mathrm{w}$ wir rozwiązywania problemów i podejmowania wyzwań, a więc zmuszają do zdobywania doświadczenia połączonego z poznawaniem historii, postaci, wydarzeń i miejsc fikcyjnych ${ }^{3}$. Jak autorzy powieści opowiadają i uczą na przykładzie swoich światów zamkniętych ramami książki, tak i twórcy gier za pomocą wirtualnej rzeczywistości przekazują odbiorcom pewne idee i koncepcje (konstruktów, zdarzeń, cech) - w tym nawet podstawowego rozumienia płci i stereotypów z nimi związanych (Prósinowski 2015). Przykładem mogą być praktyki pro-równościowe, które zaistniały w niektórych grach firmy BioWare, a także popularne The Sims 4 z 2014 roku pozwalające na tworzenie związków jednopłciowych, wychowywanie przez nie dzieci. Można zaryzykować stwierdzenie, że umieszczanie takiej zawartości w grach staje się pewnego rodzaju próbą pośredniego oswojenia graczy (w tym także dzieci, młodzieży) z występowaniem podobnych zjawisk czy wydarzeń w życiu codziennym.

Chcielibyśmy w tym miejscu odnieść się do wcześniejszych badań dotyczących mechanizmów podejmowania decyzji w grach wideo (Prósinowski 2013). Zwróćmy uwagę na pewien szczególny aspekt. Wśród badanych pojawiała się opinia, że wybory podejmowane $\mathrm{w}$ grach nie są traktowane $\mathrm{z}$ tą samą powagą, co decyzje dotyczące realnego życia. Niemniej wymagające rozstrzygnięcia dylematy wciąż zmuszają do przemyślenia decyzji - zwłaszcza, gdy wiemy, że ta będzie miała długofalowe konsekwencje (na przykład decyzje w grze Mass Effect z 2007 roku, które wpływają na fabułę Mass Effect 2 z 2010 roku i Mass Effect 3 z 2012 roku). Wstępne badania pokazały, że podjęcie niewłaściwej decyzji w grze wideo wywołuje u niektórych odbiorców wyrzuty sumienia (Prósinowski 2013). O ile podjęte działania oraz ich konsekwencje nie były wydarzeniami realnymi, tak związane z nimi emocje graczy były jak najbardziej rzeczywiste. Co ciekawe, chociaż możliwość samodzielnego decydowania oraz borykania się z ich konsekwencjami naraża odbiorcę na rodzaj emocjonalnego dyskomfortu, wątpliwości moralne oraz żal z powodu podjętych działań, zdecydowana większość graczy ceni sobie taką szansę $\mathrm{i}$ jest $\mathrm{z}$ niej zadowolona.

Graczy pytano również o to, czym kierują się, podejmując decyzje w grze. Badani mieli do wyboru przekonania moralne, odgrywanie postaci, ułatwienie rozgrywki oraz gratyfikację w postaci na przykład złota czy przedmiotów. Respondenci najczęściej wskazywali na kierowanie się własnymi przekonaniami moralnymi;

3 Chociaż nierzadko tworzonych na podstawie rzeczywistych lokacji; zdarza się, że miejsca z gier są w mniejszym lub większym stopniu wzorowane na świecie realnym. 
na drugim miejscu znalazło się odgrywanie postaci ${ }^{4}$. Sugeruje to, że gry wideo nie tylko rozbudzają kreatywność, ale także - poprzez podejmowanie decyzji i stawianie dylematów moralnych - mogą uwrażliwiać graczy na różne problemy społeczne i filozoficzne. Gracze zapytani o wartości edukacyjne w grach sami wskazywali na przykład „rozwijanie świadomości, budowanie hierarchii wartości” lub że „[...] podejmowanie decyzji w grach uczy brania odpowiedzialności za swoje czyny oraz zmusza do głębszych przemyśleń na temat problemu".

Nie jest to jednak jedyny możliwy aspekt wpływu gier wideo na graczy. Jak wynika z wystąpienia Daphne Bavelier (2012), gry pozwalają na wywoływanie konkretnych zmian w mechanizmach poznawczych odbiorcy (chociażby prędkość przeskakiwania pomiędzy różnymi zadaniami czy wzrost uwagi w obserwacji wielu elementów w tym samym czasie).

Czy jednak można to już nazwać wzrostem kreatywności lub postawy twórczej? Jest to na pewno wstęp, do tego, co może nastąpić dalej.

\section{Kreatywne odpowiedzi na gry wideo}

Poprzez działanie w immersyjnym środowisku gracz uczestniczy we współkreacji zastanej, quasi-otwartej rzeczywistości. Poznaje wizerunki, miejsca, postaci, historię i aktywnie reaguje na nie. Rozpatrując to w kontekście pola badawczego nauk pedagogicznych, gry dysponują potencjałem, by odnosić znaczące sukcesy tam, gdzie wielu wykwalifikowanych wychowawców i edukatorów boryka się z problemami.

Postawę twórczą dziecka starają się rozwijać na przykład nauczyciele. Wincent Okoń opisuje twórczość dziecka w ten oto sposób:

1) twórczość plastyczna dzieci; 2) w szerszym znaczeniu wielostronna działalność, której owocem są nowe i oryginalne wytwory w dziedzinie poznania, sztuki i techniki; może nią być zarówno rozwiązanie problemu naukowego, skonstruowanie oryginalnego urządzenia technicznego czy zaprojektowanie oryginalnego konkursu, jak i ułożenie wierszyka, skomponowanie piosenki czy namalowanie obrazu (Okoń 2001: 413).

Twórczością będzie więc proces konstruowania czegoś w odpowiedzi na określone zadania czy potrzeby. Łączy się z kreatywnością w zakresie wytwarzania nowych idei i pomysłów (Maciuszek 2002). Podejmowanie nowych działań i gromadzenie związanych z nimi doświadczeń, które odpowiadają konkretnym potrzebom (poznawczym, emocjonalnym) i problemom, stanowi formę rozwijającej, twórczej aktywności.

Kolejnym ważnym krokiem jest wskazanie tego, co kreatywne (z perspektywy odbiorców) i bezpośrednio powiązane z grami wideo. Pomińmy dydaktyczny aspekt dyskutowania i wyrażania opinii na temat gier, fabuły, postaci, wspomagający

${ }^{4}$ Badania należałoby rozwijać dalej (cytowany tekst obejmował próbę 171 osób), by dotrzeć do większej liczby graczy. Już na tym etapie jednak widać niemałe znaczenie moralności w procesie decydowania w grach. 
rozwój umiejętności komunikacyjnych ${ }^{5}$. Skupmy się raczej na zjawisku tworzenia tak zwanych fanfiction (lub czasami skrótowo fanfic), fanartów i fanowskich modyfikacji do gier. Będziemy je rozpatrywać w tej właśnie kolejności.

Terminem fanfiction określa się tekstowe odpowiedzi na różne produkty między innymi na gry wideo - przyjmujące zwykle postać opowiadań, opisów, kontynuacji wydarzeń, tak zwanych spin-offów i podobnych. Fani, motywowani zainteresowaniem lub sympatią do fikcyjnych postaci (bądź innych elementów danego uniwersum), tworzą własne teksty zainspirowane światem konkretnej gry wideo. Działalność ta ma zwykle charakter oddolny, niezorientowany na zysk, jednocześnie wytwarzający nową jakość danej produkcji. W jego wyniku oczekiwania i potrzeby graczy zaczynają kształtować ostateczną formę produktu. Nauczyciele często nie zdają sobie sprawy, że uczniowie lubią pisaći że podejmują tego rodzaju aktywność. Twórczość fanowska jest wyraźnie odróżnialna od problematycznego „szkolnego pisania" postrzeganego jako przykra konieczność. Przyjrzyjmy się liczbie fanficów. Na jednej z najpopularniejszych stron internetowych poświęconych temu gatunkowi twórczości - www.fanfiction.net - znajduje się ponad 300 tys. (ponad 340 tys., jeśli wliczyć w to teksty odnośnie dwudziestu najpopularniejszych tytułów gier6) opowiadań obracających się jedynie wokół motywów z gier wideo.

Fanarty - podobnie jak fanfiction - są społeczną formą reakcji na popularne produkcje kultury popularnej: seriale, filmy, gry. Odpowiedź na nie przychodzi $\mathrm{w}$ formie prac graficznych wykonanych różnymi technikami - fotografii i fotomanipulacji, rysunku, kolażu, malarstwa itd. Do zróżnicowanych form fanartu zaliczyć można także tak zwany cosplay7. Wielu tworów plastycznych znaleźć można rozproszonych po całym internecie, między innymi na popularnej stronie deviantArt (www.deviantart.com), gdzie różni artyści dzielą się wszystkim, co można zaliczyć do kategorii „art”.

Fanarty są zróżnicowane pod względem jakości wykonania i wartości artystycznej. Niekiedy są to prace na wysokim, profesjonalnym poziomie lub wprost przeciwnie - mogą być rezultatem pierwszych artystycznych wysiłków, będących krokiem w kierunku rozwijania i udoskonalania warsztatu i techniki. Poprzez zaangażowanie, wynikające z zamiłowania do danej gry, wzmocnieniu ulega motywacja do polepszania efektów własnej pracy. Trudno zaprzeczyć, że w niektórych przypadkach wytworzone w ten sposób prace zaskakują uzyskaną wartością estetyczną. Zamieszczona grafika BG: Friendly Arm stanowi przykład interakcji pomiędzy doskonaleniem warsztatu graficznego oraz indywidualnymi zainteresowaniami autorki w zakresie gier wideo (w tym przypadku Baldur's Gate). Połączenie profesjonalnej wiedzy oraz pasji stanowi punkt wyjścia do powstania nowej formy artystycznej.

${ }^{5}$ Chociaż i tu nauczyciele zapominają, że na materiałach $\mathrm{w}$ postaci gier można uczyć budowania wypowiedzi, jednocześnie wychodząc naprzeciw zainteresowaniom i fascynacjom uczniów.

${ }^{6}$ Liczba tekstów na dzień 18 czerwca 2015 roku.

7 Inicjatywa polegająca na przebieraniu sie za postacie znane z komiksów, gier, filmów, animacji, seriali i innych produktów kultury popularnej. Nierzadko jest połączone z imitowaniem manier czy sposobu mówienia postaci. Częsty element różnego rodzaju konwentów oraz festiwali. Zdarza się, że fani (osoby przebierające się) własnoręcznie szyją/tworzą wszystkie elementy stroju. 


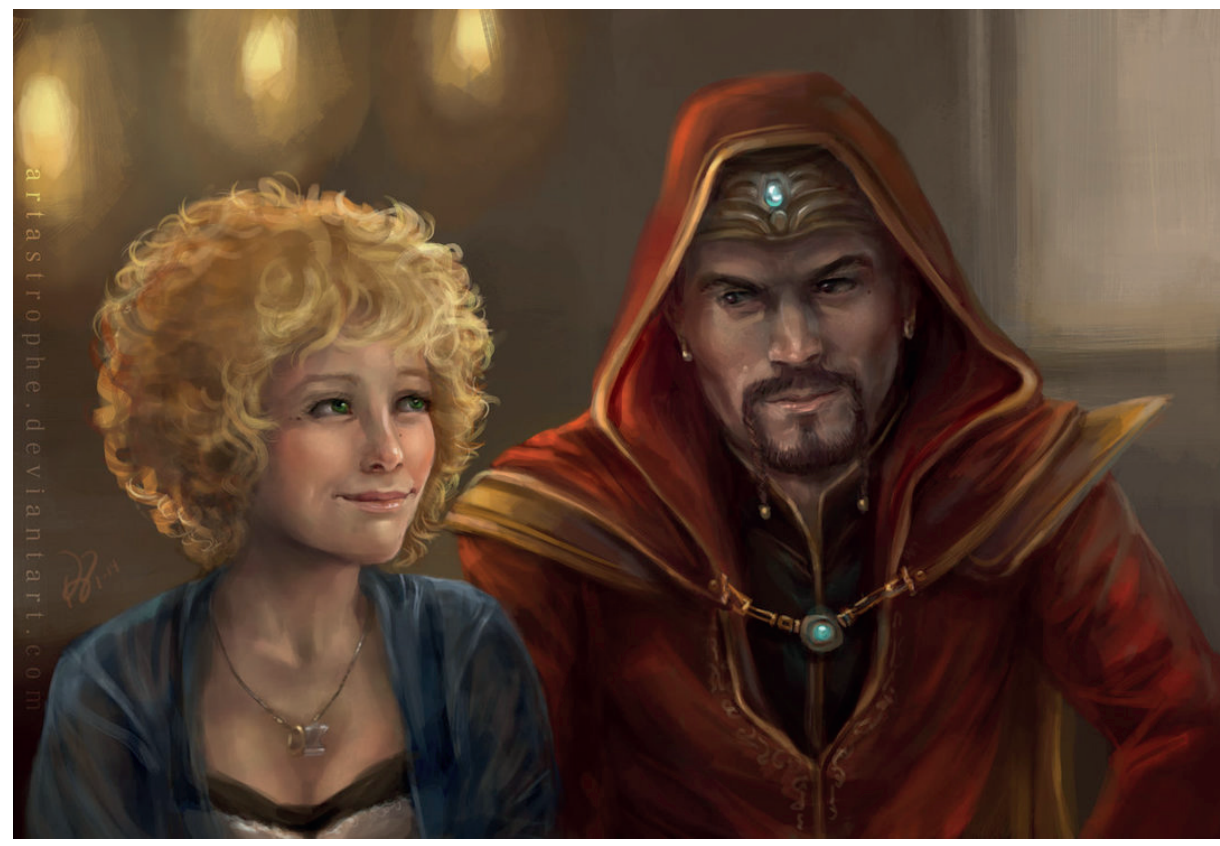

Il. 1. BG: Friendly Arm autorstwa artastrophe - przykład fanartu.

Źródło: http://artastrophe.deviantart.com/art/BG-Friendly-Arm-437523349 [dostęp: 12.03.2015].

Badania dotyczące twórczości fanów zdają się potwierdzać tezę o kreatywnym potencjale tego typu działalności (Manifold 2007). Warto zaznaczyć, że gdy zapytani o naukę i rozwój swoich zdolności artystycznych, respondenci (autorzy fanartów i kostiumów cosplayowych) zaznaczają, że nauczyli się tworzyć samodzielnie, w czasie wolnym, dzięki wewnętrznej motywacji ukierunkowanej na takie, a nie inne zainteresowania.

Kolejną formą twórczości jest pisanie modyfikacji do gier wideo (tak zwanych modów). Wielu graczy w różnym wieku pod wpływem poczucia niedosytu oraz inspiracji po przejściu gry decyduje się na tworzenie własnych modyfikacji, dodanie nowych lokacji, postaci, dialogów, przedmiotów, grafik czy innym elementów. Tutaj mamy do czynienia już z multimedialnym przekazem połączonym z umiejętnością kodowania nowych tworów - w ten sposób autorzy wyrażają się już nie tylko poprzez tekst czy grafikę, ale także rozwijają swoje kompetencje technologiczne, sami sobie stawiają zadania problemowe, pracują z silnikiem konkretnej gry wideo. Przykładem stron zrzeszających "modderów” mogą być Spellhold Studios, Gibberlings3 oraz Pocket Plane Group (dla serii Baldur's Gate [rok 1998, 2000] oraz Icewind Dale [rok 2000, 2002]) czy Nexus Mods dla gier z różnych gatunków. W przypadku tworzenia dodatków-modów twórca jest jednocześnie odbiorcą danej produkcji. Pisząc dodatek, kieruje się własnymi doświadczeniami z daną grą, wyciąga z nich wnioski, a na ich podstawie generuje nowe treści.

Wszystkie trzy powyższe formy działalności twórczej łączą się z grami wideo. Stwierdzenie zatem, że gry mogą w pewnych warunkach inspirować do 
kreatywnej, innowacyjnej działalności, stanowiąc tym samym wartościowe pole eksploracji pedagogów, wydaje się zasadne.

Opisane tu formy działalności są odpowiedziami na potrzeby wewnętrzne graczy, są czymś nowym, bo stworzonym bezpośrednio przez autorów (dzięki inspiracjom z gier i innych tekstów kultury). W ramach procesu twórczego dochodzi do reinterpretacji gry przez odbiorcę - wytwory fanowskie nigdy nie będą charakteryzować się tą samą jakością, co treści zaprezentowane w oryginalnej grze.

Warto także wspomnieć o aspekcie społecznym tego typu twórczości - przy okazji tworzenia (czy to fanficów, fanartów czy modów) twórcy łączą się w mniej lub bardziej złożone społeczności, w których obrębie wymieniają się opiniami, dziełami, pomysłami czy refleksjami. Dzięki temu - tuż obok warsztatu twórczego - doskonalą kompetencje społeczne. Społeczności te budują także poczucie wspólnoty celu i zamiłowania. Tworzące się grupy fanów nazywane są fandomami. Związane są z nimi nie tylko konkretne fora czy portale, ale także konwenty i mniej publiczne spotkania połączone z aspektem rozrywkowym - mniej lub bardziej zorientowanym na wspólne zainteresowania. W fandomach dochodzi do spontanicznej, nieformalnej edukacji, która bazuje na rozwoju twórczości i na współdziałaniu, współrecenzowaniu tworzonych w grupie dzieł czy dzieleniu się spostrzeżeniami i informacjami zarówno z kręgu zainteresowań, jak i (często poprzez dygresję) spoza niego. Co więcej, poprzez więzi społeczne i atrakcyjność tychże grup - jak pisze Piotr Siuda (2008) za Henrym Jenkinsem - członkowie grupy uczą się aktywniej i z większym zaangażowaniem. Dzięki tworzeniu społeczeństw wirtualnych i umieszczaniu swojej twórczości pojawiają się także nowe przestrzenie istnienia znanych społecznych dyskursów. Przykładem może być tematyka seksualności i coming outu osób homo- lub biseksualnych - poprzez tworzenie i upublicznianie homoerotycznych fanartów niektórzy z autorów mogą oswajać się ze swoją seksualnością lub dokonują uświadomienia innym swoich preferencji seksualnych (Dennis 2010). Fanart staje się w tym momencie rodzajem pracy nad świadomością własnej cielesności, a także przeobraża się w wiadomość i rodzaj wyznania. Jeffery P. Dennis pisze:

Także tworzenie oraz zamieszczanie [na stronach internetowych - P.P., P.K.] homoerotycznych obrazów i odpowiadanie na komentarze fanów (także pytania typu ,jesteś gejem?”) zdaje się być swojego rodzaju częścią procesu coming outu w obliczu kulturowych domniemań na temat uniwersalności heteroseksualnych pragnień (Dennis 2010: 11) ${ }^{8}$.

Dennis jest zdania, że fandomy stają się istotnym społecznie miejscem dyskusji, ponieważ pojawiają się w tej przestrzeni głosy i wyznania realnych ludzi, zdigitalizowane echa ich życia pozawirtualnego.

Nabiera to jeszcze większego znaczenia przez pryzmat kultury Polski. Jak wspomina Marek Sokołowski (2012: 251-252),

Wątki homoseksualne w polskich mediach są wciąż tematem tabu, występują rzadko i są bardzo często zmarginalizowane. Świadomość społeczna dotycząca wizerunku gejów

8 Tłumaczenia - P.K, P.P., jeśli nie zaznaczono inaczej. 
w Polsce [...] jest kreowana przez seriale [...]. W Polsce wizerunek homoseksualistów $\mathrm{w}$ mediach oparty jest głównie na stereotypach i schematach.

Można więc stwierdzić, że artystyczny coming out, tworzenie homoerotycznych obrazów, dzielenie się swoimi dziełami, dyskusja - chociaż w społeczności w pewnej mierze zamkniętej - staje się zauważalną i wartą wspomnienia przeciwwagą dla tabuizacji i marginalizacji wątków homoseksualnych w Polsce.

Oczywiście treści homoerotyczne nie są jedynymi ważnymi kwestiami wirtualnych flirtów. Romanse (czy w ogóle relacje) pomiędzy postaciami z gier nierzadko stają się inspiracją do tworzenia artystycznych ilustracji czy barwnych fantazji ${ }^{9}$.

\section{Uwagi końcowe}

Wszystkie wspomniane przejawy twórczości w dużej mierze funkcjonują na uboczu edukacji. Tutaj rodzi się pytanie, czy możliwe jest włączenie inicjatyw fanfiction, fanart i fanowskich dodatków do edukacji? Wielu uczniów tworzy, rysuje, pisze w sposób niewidzialny dla szkoły (nauczycieli, instruktorów, edukatorów), co sprawia, że ich osiągnięcia pozostają niezauważone. Co więcej, w niektórych przypadkach wsparcie nauczycieli czy pedagogów mogłoby pomóc w rozwoju talentów. Idąc krok dalej, jednym z zadań szkoły powinno być ukazanie możliwości realizacji twórczo-osobistej, ekspresji, a opisane wyżej formy są właśnie możliwością, potencjałem, o których nie mówi się w większości placówek. Trudno więc znaleźć powód, by nie pozwalać uczniom tworzyć fanfiction na zajęciach językowych (polski, angielski itd.), rysować, malować fanartów (zarówno klasycznie, jak i wirtualnie, przy użyciu programów graficznych) na zajęciach plastycznych czy nie wspomnieć chociażby o czymś takim jak modyfikacje fanowskie na zajęciach z informatyki. Byłoby to jednocześnie wyjście naprzeciw zainteresowaniom niektórych z uczniów.

Oczywiście trzeba pamiętać, że nie wszystkie gry wpływają na graczy w taki sam sposób. Owszem, istnieją gry pełne przemocy, gry logiczne, pozbawione fabuły czy gry powielające stereotypy, jednak wszystkie one dysponują swym własnym potencjałem.

Wśród wielu tytułów gier znajdziemy też takie, które bazują na kreatywności graczy już na samym poziomie rozgrywki. Można tutaj wymienić takie tytuły jak znany Minecraft (wydany przez Mojang AB w 2011 roku), czy mniej znane Cargo! Quest for Gravity (Ice-Pick Lodge, rok 2011) - grę, w której - poza podążaniem za fabułą - mamy okazję bawić się w „małego inżyniera”, budować wszelakie jeżdżące, latające i pływające pojazdy z elementów, które znaleźliśmy w cyfrowym świecie. Istnieją także gry, których celem jest pobudzanie wyobraźni czy rozwijanie umiejętności pisarskich wraz z umiejętnością snucia opowieści - można tu

\footnotetext{
${ }^{9}$ Kwestie erotyki rozwija także Magdalena Cielecka (2014), dodatkowe informacje zawarłem w tekście dotyczącym konstruktów płci i seksualności (Prósinowski 2015), lecz oba te teksty wymagają obszerniejszych kontynuacji.
} 
wymienić chociażby wydaną w 2014 roku grę Elegy for a Dead World (stworzoną przez Dejobaan Games, LLC).

Gry fabularne - tak jak literatura - wpływają na odbiorców przez historie, które opowiadają. Potrafią uwrażliwiać już najmłodszych poprzez opowiadanie barwnych, a także bogatych w emocje historii. Najświeższym przykładem może być wydana stosunkowo niedawno platformowa gra zręcznościowa Ori and the Blind Forest z 2015 roku (docelowo dla dzieci powyżej siódmego roku życia, lecz grywalna także dla niektórych młodszych odbiorców). Gra - poza treningiem manualnym oferuje również historię bogatą w smutek, radość, współczucie. Zaspokaja potrzebę obcowania z rozwiniętym wachlarzem emocjonalnym, pozawala poznać uczucia w tym przypadku z pozycji bezpiecznego fotela - jednocześnie bawiąc.

Co istotne, gry wywołują dyskusje, które są tak ważne dla rozwoju nauk społecznych oraz dla zwrócenia uwagi na to, co niezbadane, ciekawe, kontrowersyjne. W tematyce gier wideo jest jeszcze wiele obszarów, których pedagogika nie zbadała, a wiadomo, że dzieci już od najmłodszych lat zaczynają grać. Gry wideo są nowym wyzwaniem, które wymaga innego podejścia i wyzbycia się strachu przed zjawiskami związanymi z wirtualną rozrywką. To teksty kultury, które są z łatwością odczytywane przez wszystkich: dzieci, młodzież, dorosłych czy seniorów. Na wszystkie te grupy mogą wywierać wpływ, nie na każdego taki sam, ale sama jego możliwość ma znaczenie. Tu pojawia się przez pedagogami (czy badaczami społecznymi w ogóle) nowe zadanie: dokładne zrozumienie zjawiska poparte solidnymi badaniami - zarówno jakościowymi, jak i ilościowymi.

Rozważmy pragnienie graczy istnienia w światach wirtualnych pełnych różnorodnych bodźców. Następnie zwróćmy uwagę na słowa Tomasza Kalbarczyka z tekstu poświęconego myśli Richarda Rorty'ego:

Dla promowania wyobraźni i tolerancji zaleca autor Filozofii i zwierciadła natury, jako minimum, zapewnienie uczniom wielu różnorodnych źródeł wiadomości, tak by poruszając się wśród książek, obrazów i filmów odnaleźli inspirację do tworzenia. [...] mamy prawo oczekiwać, że odnajdą oni w końcu sposób, którym na nowo opiszą zarówno siebie, jak i swoją społeczność. Najzdolniejsi z nich wprowadzą zmiany do kanonu wiedzy proponowanego przez Hirscha i jemu podobnych, wniosą nowe elementy do procesu socjalizacji swoich dzieci i jeszcze lepiej przygotują je do autonomicznego rozwoju po osiągnięciu dojrzałości (Kalbarczyk 2007: 59).

W naszych czasach, w erze dążenia do sprawiedliwości, wolności oraz rozwoju warto zaznaczyć, że także gry - obok książek, obrazów i filmów - istnieją jako odrębny, pełnoprawny element mający znaczenie w kontekście źródeł informacji, dawania okazji do zdobywania doświadczenia, ergo do rozwoju i filozofowania, bo także gry wideo w treści swej poruszają tematy moralności, życia społecznego, wolności oraz wiedzy. 


\section{Literatura:}

Bauman Z., May T., 2004, Socjologia, tłum. J. Łoziński, Poznań: Wydawnictwo Zysk i S-ka.

Bavelier D., 2012, Gry wideo a mózg, http://www.ted.com/talks/daphne_bavelier_your_brain_on_video_games?language $=\mathrm{pl} \# \mathrm{t}-1053457$ [dostęp: 7.03.2015].

Bougsiaa H., 2013, Children within Mobile Technology: Interacting and Learning, "Ars Educandi" t. 10.

Cielecka M., 2014, Brzemię interaktywności - erotyka i seksualność w grach komputerowych, „Replay. The Polish Journal of Game Studies" nr 1, http://repozytorium.uni.lodz.pl:8080/ xmlui/handle/11089/8850 [dostęp: 5.02.2016].

Dennis J.P., 2010, Drawing Desire: Male Youth and Homoerotic Fan Art, "Journal of LGBT Youth" Vol. 7, Iss. 1, http://www.tandfonline.com/doi/abs/10.1080/19361650903507734\#.VQMIw-EXvwY [dostęp: 13.03.2015].

Filiciak M., 2006, Wirtualny plac zabaw. Gry sieciowe i przemiany kultury wspótczesnej, Warszawa: Wydawnictwa Akademickie i Profesjonalne.

Kalbarczyk T., 2007, Liberalizm i wychowanie. Richarda Rorty'ego filozofia edukacji, „Kultura i Edukacja" nr 2.

Maciuszek J., 2002, Kreatywna postawa - narzędzia i strategie twórczego działania w NLP, http:// www.psychologia.edu.pl/czytelnia/50-artykuly/918-kreatywna-postawa-narzedzia-i-strategie-tworczego-dzialania-w-nlp.html [dostęp: 8.03.2015].

Manifold M.C., 2007, Culture Convergence or Divergence? Spontaneous Art-Making and Participatory Expression in the Private and Collective Lives of Youth [w:] Art Education as Critical Cultural Inquiry, ed. J.A. Park, Seoul: Mijinsa.

Okoń W., 2001, Nowy stownik pedagogiczny, Warszawa: Wydawnictwo Akademickie "Żak”.

Olszewski P., 2011, Tygodnik Polityka: "Fabuła gier komputerowych zasadza się na tym, żeby schwytać dziewczynę i zbiorowo zgwatcić", http://gamezilla.komputerswiat.pl/newsy/2011/37/tygodnik-polityka-bo-na-takie-wzorce-trafiaja-chocby-w-grach-komputerowych-ktorych-fabula-zasadza-sie-na-tym-zeby-schwytac-dziewczyne-i-zbiorowo-zgwalcic [dostęp: 8.03.2015].

Prósinowski P., 2013, Sumienie graczy: podejmowanie decyzji w fabularnych grach komputerowych w kontekście socjalizacji i wrażliwości społecznej, „Ars Educandi” t. 10.

Prósinowski P., 2015, To, co męskie, to, co kobiece. Konstrukty płci i seksualności w grach komputerowych [w:] Codzienność, performatywność, demokracja: pedagogika wobec norm życiowych i problematyki nienormatywności, red. L. Kopciewicz, B. Simlat-Żuk, Gdańsk: Wydawnictwo Naukowe Katedra.

Siuda P., 2008, Edukacyjne i wychowawcze aspekty uczestnictwa w społecznościach fanów (fandomach) [w:] Media w edukacji - szanse i zagrożenia, red. T. Lewowicki, B. Siemieniecki, Torun: Wydawnictwo Adam Marszałek.

Sokołowski M., 2012, W lustrze mediów, Torun: Wydawnictwo Adam Marszałek.

Szeja Z.J., 2004, Gry fabularne - nowe zjawisko kultury wspótczesnej, Kraków: Wydawnictwo Rabid.

Zając M., 2013, Aplikacje książkowe dla dzieci młodszych: między książą a gra komputerowa, "Ars Educandi" t. 10.

Zielińska E., 2015, Wptyw gier komputerowych na zdrowie psychiczne i fizyczne dziecka, http:// szkolnictwo.pl/index.php?id=PU7818 [dostęp: 8.03.2015].

Filmy:

Głowacki M., 2014, Szkoła, odc. 51, http://player.pl/seriale-online/szkola-odcinki,2395/odcinek-51,S00E51,33779.html [dostęp: 5.01.2016]. 
Hofer J., 2014, Rozmowy w toku: Moje dziecko wpadło w komputerowy natóg, http://rozmowywtoku.tvn.pl/wideo,1027,v/moje-dziecko-wpadlo-w-komputerowy-nalog-fragment-programu,1028068.html [dostęp: 5.01.2016].

Liebert S., Łukański M., Pitala K., 2014, Kącik filmowy "Coś tu nie gra” - Ojciec Mateusz kontra gry komputerowe, http://tvgry.pl/?ID=4823 [dostęp: 9.03.2015].

Żmijewski A., 2014, Ojciec Mateusz, odc. 144: Magiczne zwierciadło.

Ludografia:

BioWare, 2000a, Baldur's Gate 2, CD Projekt.

BioWare, 2000b, Icewind Dale, CD Projekt.

BioWare, 2002, Icewind Dale 2, CD Project.

BioWare, 2007, Mass Effect, CD Project.

BioWare, 2010, Mass Effect 2, CD Project.

BioWare, 2012, Mass Effect 3, CD Project.BioWare, 1998, Baldur's Gate, CD Projekt.

Dejobaan Games, LLC, 2014, Elegy for a Dead World, Dejobaan Games, LLC.

Ice-Pick Lodge, 2011, Cargo! Quest for Gravity, bitComposer Games.

Maxis, 2014, The Sims 4, Electronic Arts Polska.

Mojang AB, 2011, Minecraft, Mojang AB.

Moon Studios, 2015, Ori and the Blind Forest, Microsoft Studios.

\begin{abstract}
Abstrakt
Na gruncie dyscyplin pedagogicznych wyrosła obszerna narracja skoncentrowana na negatywnym obrazie gier wideo. Medium to doczekało się obszernej literatury omawiającej zarówno realne, jak i czysto hipotetyczne zagrożenia z nim związane. W artykule dyskutujemy nad potencjałem gier do pobudzania kreatywności oraz uwrażliwiania na to, co w społeczeństwie uważa się za problematyczne, podlega tabuizacji. Wskazujemy tu na gry jako teksty kultury, które dysponują swym własnym potencjałem i możliwościami edukacyjnymi w zakresie rozwoju oraz inspirowaniu odbiorców.
\end{abstract}

\title{
Słowa kluczowe
}

gry wideo, kreatywność, wrażliwość społeczna, edukacja, emocje, kultura

\section{Summary}

\section{Video Games and Creativity: On Potential and Narration of Fear}

There is a massive amount of pedagogical literature about video games, constructing a negative image of the medium.

There are many texts about both real and hypothetical dangerous influences of games on those who play them. In our text we discuss a specific potential of video games - the ability to support creativity and social awareness (which in some situation may break taboo). In the article we also discuss other potentials of video games along with their connotations with culture and education.

\section{Keywords}

video games, creativity, social awareness, education, emotions, culture 